\title{
Influence of climatic and hydrodynamic factors on the quarry water purification process from nitrogen compounds
}

\author{
Alexander Khokhryakov, Gennady Studenok, Andrey Studenok, Alexander Olkhovsky, and \\ Vladimir Boltyrov
}

Ural State Mining University, Environmental Engineering Department, 620144, Kuibyshev Str., 30, Yekaterinburg, Russia

\begin{abstract}
The nitrogen compounds, namely ammonium, nitrite and nitrate nitrogen, are the main substances polluting the quarry and drainage waters of mining enterprises that use the ammonium nitrate-based explosives for drilling-and-blasting rock mass preparation. In accordance with the legislation, such waters are subject to treatment prior to discharge into the water bodies. At the mining enterprises, the promising treatment method is the treated water conditioning in the flooded abandoned open-pit mines, during which the natural microbiological nitrification of ammonium and nitrite nitrogen contained in the quarry drainage waters is performed with an efficiency of more than $95 \%$. The article discusses the influence of natural climatic and hydrodynamic factors on the nitrification process according to the results of a purification process study that has been performed since 2014 until the present time at a large mining enterprise. The relevant conclusions and recommendations are given.
\end{abstract}

\section{Introduction}

Environmental protection for the health and fruitful life of present and future generations is one of the principles that is used as a guidance by most countries of the world in its policies, including Russia. Different aspects of environmental protection, including the mining industry, are the subject of various scientific studies [1-3].

The main pollutants of the discharged drainage and quarry waters of the mining enterprises are nitrogen compounds, such as ammonium, nitrite and nitrate nitrogen forms, the presence of which is caused by the use of explosives. The main component of such explosives is ammonium nitrate $\mathrm{NH}_{4} \mathrm{NO}_{3}$. At present, the ammonium nitrate explosives are widely used in the mineral raw material extraction industry that is explained by the availability and low cost of raw materials for the production of such explosives.

The availability of an ammonium form in the quarry and drainage waters is explained by the dissolution and elution of ammonium nitrate during the water hole loading. Pollution of the quarry and drainage waters with a nitrite form is caused by adsorption by 
the rock mass of nitrogen oxides formed during the explosive decomposition of blasting agents, their subsequent elution with rain and snow precipitations, and penetration of the nitrite form of nitrogen in the quarry and drainage waters. Penetration of the nitrate form of nitrogen in the waters under consideration is associated both with the ammonium nitrate dissolution process in the water wells and with the natural desorption by precipitations of nitrogen oxides previously adsorbed by the rock mass.

In addition, entry of nitrogen compounds into the quarry and drainage waters during the rock mass explosive preparation is due to the fact that the explosives are spilled during the hole loading, the wells are failed and, as a result, the main explosive component remains in the blasted rock mass. It is ammonium nitrate, the main source of pollution of the quarry and drainage waters with nitrogen compounds.

The decrease in the nitrogen compound concentration in the drainage waters can be achieved by two sets of measures:

1. Quarry water purification from nitrogen compounds in various ways.

2. Engineering and organizational measures to prevent pollution of drainage water with nitrogen compounds.

At the same time, for example, the large mining enterprises in Russia and Sweden implement a biological treatment method in practice with an efficiency of about $90 \%$ [4-8], due to the need to treat significant amounts of quarry water (about 5-10 million cubic meters annually) that in practice does not allow to use other methods.

\section{Materials and methods}

Since 2014, one of the most important Ural mining enterprises has been treating the existing quarry waters by sending them to a nearby quarry that has been watered and previously routinely flooded. The most environmentally hazardous nitrogen forms (ammonium and nitrite) are gradually decomposing in this quarry.

The process of converting the ammonium and nitrite forms of nitrogen into the nitrate form in natural water bodies and waterways represents the biological oxidation under the action of specific bacteria [9-11].

The initial phase of the ammonium ion oxidation to nitrite ions is carried out by the ammonium-oxidizing bacteria (Nitrosomonas, Nitrococcus, Nitrosolobus, etc.) that can most simply be described by the following chemical equation:

$\mathrm{NH}_{4}^{+}+1,5 \mathrm{O}_{2} \rightarrow \mathrm{NO}_{2}^{-}+\mathrm{H}_{2} \mathrm{O}+2 \mathrm{H}^{+}$.

The further oxidation process of the nitrite form of ion $\left(\mathrm{NO}_{2}^{-}\right)$to nitrate form occurs using the nitrite-oxidizing bacteria (Nitrobacter, Nitrococcus, etc.):

$\mathrm{NO}_{2}^{-}+0,5 \mathrm{O}_{2} \rightarrow \mathrm{NO}_{3}^{-}$

According to the study results and its analysis related to the nitrification processes in various water bodies, it has been determined that the nitrification intensity on average has a value of 0 to $32 \mathrm{mg} \mathrm{N} /\left(\mathrm{dm}^{3}\right.$.day) and depends on the lake ecosystem type [11].

The analysis of changes in the content of ammonium and nitrite nitrogen in the flooded quarry used to clean the quarry waters of the productive quarry of a large mining enterprise over a six-year observation period (2014-2019) compared with its contents in the incoming quarry waters allowed to apply the "perfect-mixing reactor" model to the controlled water layer. According to this model, during the course of a biological nitrification chemical reaction due to mixing, the substance concentrations are the same throughout the volume and are fluctuated with time only.

For a controlled water layer in a flooded quarry, the process rate of decreasing the concentration of ammonium and nitrite nitrogen under the combined influence of biotic (nitrification) and abiotic factors (dilution of the incoming quarry waters by rain and snow precipitations, as well as the groundwaters) is calculated by the following equations: 


$$
\begin{gathered}
\begin{array}{c}
\text { Ammonium nitrogen } \\
W_{a m}=\left(C_{\text {nam }}-C_{\text {qam }}\right) / d t, \mathrm{~g} / \mathrm{m}^{3} \cdot \mathrm{day} \\
\text { Nitrite nitrogen }
\end{array} \\
W_{\text {nit }}=\left(d C_{\text {nam }}+C_{n}^{\text {nit }}-C_{q}^{\text {nit }}\right) / d t, \mathrm{~g} / \mathrm{m}^{3} \cdot \mathrm{day},
\end{gathered}
$$

where:

$\mathrm{C}_{\text {nam и }} \mathrm{C}_{\mathrm{n}}{ }^{\text {nit }}$ - average monthly concentration of ammonium and nitrite forms of nitrogen in the quarry waters received for treatment, $\mathrm{g} / \mathrm{m}^{3}$;

$\mathrm{C}_{\text {qam }}$ и $\mathrm{C}_{\text {qnit }}$-average monthly concentration of ammonium and nitrite forms of nitrogen in the abandoned quarry according to the monthly control results, $\mathrm{g} / \mathrm{m}^{3}$;

$\mathrm{dC}_{\text {nam }}$ - primary increase in the concentration of the nitrite form of nitrogen due to the transition of the ammonium nitrogen to the nitrite form, $\mathrm{g} / \mathrm{m}^{3}$;

$\mathrm{dt}$ - the observation period, day.

\section{Results and discussion}

The results of the performed model calculation have showed that at the observed concentrations of ammonium and nitrite nitrogen in the waters received for treatment at the abandoned flooded quarry, the process rates of reduction in their concentrations are as follows:

- for the ammonium form of nitrogen $-0.17 \mathrm{~g} / \mathrm{m}^{3} \cdot \mathrm{day}$;

- for the nitrite form of nitrogen $-0.29 \mathrm{~g} / \mathrm{m}^{3} \cdot$ day.

The obtained values of the average nitrification rate are close to the published data on the nitrification rates of nitrification of ammonium and nitrite forms observed in the natural lakes $[11,12]$.

In general, the analysis of the results of using the abandoned quarry as a sedimentation accumulator tank for the quarry water from the productive quarry for its purification from the nitrogen compounds has showed the following: for 6 years of its operation a stable efficiency of water purification from the most environmentally hazardous pollutants (ammonium and nitrite nitrogen) has been achieved at $97-98 \%$ of its initial content in the drainage waters.

The dynamic analysis of the removal of nitrogen compounds from the drainage waters of the productive quarry shows that their greatest values occur during the warm period of the year (April-October) that is due to the largest volumes of formation and discharge of the quarry drainage water formed as a result of precipitations to the drainage area of the quarry.

According to the results of continuous monitoring performed during the warm period of the year (April - August), the observed ammonia nitrogen concentration in the water of the abandoned flooded mine does not exceed the established MAC values for the fishery water bodies (according to the results of constant observations, they are at the level of $0.1-0,6$ MAC) when it is filled with the drainage water from the productive quarry with a maximum ammonium nitrogen concentration not exceeding $8 \mathrm{mg} / \mathrm{dm}^{3}$. Due to the initial increase in nitrite nitrogen content as a result of the ammonia nitrogen conversion into nitrite nitrogen, the established MAC values for the fishery water bodies during the warm period of the year are not achieved (according to the results of constant observations, the concentration is at a level of 3-13 MAC). This is due, inter alia, to more stringent MAC standards established for nitrite nitrogen the treated sewage (quarry) waters are discharged into the fishery water bodies (for ammonium nitrogen it is equal to $0.4 \mathrm{mg} / \mathrm{dm}^{3}$, for nitrite it is equal to 0.02 $\left.\mathrm{mg} / \mathrm{dm}^{3}\right)[13]$. 
Another factor affecting the final concentration of nitrite nitrogen is the hydrodynamic factor of mixing the fresh drainage waters entering the flooded mine, with the water already accumulated in it and purified during the nitrification process. During the cold period of the year, as a result of the formation of the hydrodynamic temperature inversion regime (temperature stratification), the fresh drainage water entering the flooded mine with a lower concentration of nitrogen compounds does not mix with the higher concentration of drainage water that has previously entered the quarry during the warm period. At this time such water is located in the lower layers and gradually undergo the nitrification process.

The nitrite nitrogen concentration values, close to or equal to the MAC values $(0.75-1.1$ $\mathrm{MAC}$ ), are observed in the controlled upper water layer only during the cold period of the year (December - March) with the minimal values of total intake of ammonium and nitrite nitrogen by the drainage waters at a level not exceeding $4 \mathrm{t} / \mathrm{month}$ and concentrations up to $6 \mathrm{mg} / \mathrm{dm}^{3}$. This is due to the fact that the formation volume of the quarry drainage water during the cold period of the year is much lower (up to $30 \%$ of the annual volume of quarry drainage water) that leads to a relevant decrease in the nitrogen compound removal compared to the warm period with an almost constant flow rate of explosives.

The decrease in nitrite nitrogen concentrations during the cold period also occurs as a result of changes in the hydrodynamic regime of a stagnant basin (flooded mine). In the winter cold period, a stagnation regime is occurred during which there is no mixing of the upper cold water layers (temperature below $4^{\circ} \mathrm{C}$ ) with the warmer (temperature of $4^{\circ} \mathrm{C}$ ) lower layers (Figure 1) $[14,15]$. As a result, the drainage waters that has undergone biological treatment for a longer time, and, therefore, that are less polluted by ammonium and nitrite nitrogen, almost do not mix with the waters that have been entered during the warm period of the year.

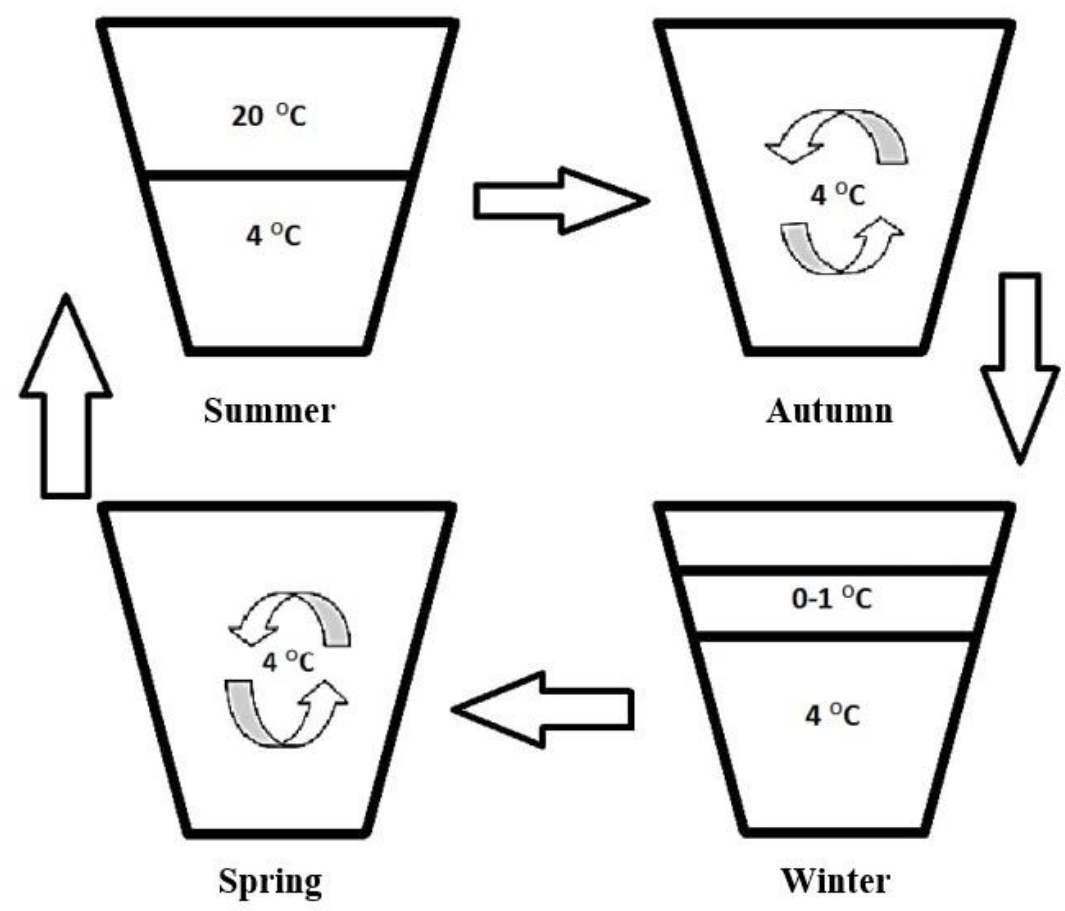

Fig.1. Temperature stratification (temperature distribution by depth) at different times of the year in a flooded abandoned open-pit mine. 


\section{Conclusion}

Analysis of constant observations of the ammonium and nitrite nitrogen concentration distribution over the depth of the water layer in the abandoned mine used to accumulate the treated drainage waters has showed a decrease in its concentration in the deeper layers, compared to the upper layer that is entered by the untreated drainage waters during the warm period of the year. In the autumn period, these waters are turned up and by the beginning of winter this process is completed.

The combination of these factors leads to the fact that, despite the deceleration of biological purification processes during the period of sub-zero air temperatures, during the cold period the upper water layer of the abandoned mine shows the nitrite nitrogen concentrations close to the MAC values.

This phenomenon can be used by the mining enterprises using used the open-pit mines for the purification of waters contaminated with nitrogen compounds, for the removal of purified water in the winter, that is, at a time when the combination of the climatic and hydrodynamic factors described above in the upper subglacial water layer maximally contributes to the lower concentrations of nitrogen compounds.

\section{References}

1. V.A. Pochechun, M.V. Arkhipov, V.V. Kuchin, Ecology and Industry of Russia, 21(1), 30-35 (2017)

2. S.Ya. Davydov, N.G. Valiev, N.V. Grevtsev, L.N. Oleinikova, Sustainable Development of Mountain Territories, 11(3), 273-283 (2019)

3. V.E. Konovalov, A.I. Semyachkov, V.A. Pochechun, IOP Conference Series: Earth and Environmental Science, 321(1), N 012053 (2019)

4. G. Evdokimova, L. Ivanova, N. Mozgova, V. Myazin, N. Fokina, Ecology and industry of Russia, 19(9), 35-41 (2015)

5. T.M. Atavina, Water Magazine, 1(125), 8-11 (2018)

6. G.A. Studenok, Izvestiya Vuzov. Mining Journal, 3, 32-39 (2018)

7. K. Mattila, G. Zaitsev, J. Langwaldt, Biological removal of nutrients from mine waters, 99 (2007)

8. S. Chlot, Nitrogen Effluents From Mine Sites in Northern Sweden. Nitrogen Transformations and Limiting Nutrient in Receiving Waters URL:http://www.divaportal.org/smash/get/diva2:990076/FULLTEXT01.pdf

9. E.S. Bikbulatov, E.M. Bikbulatova. I.E. Stepanova, Hydroxylamine and hydrazine in aquatic ecosystems, 128 (Rybinsk: Publishing House Rybinsk Printing House OJSC, 2007)

10. S.I. Kuznetsov, A.I. Saralov, T.N. Nazina, Microbiological processes of the carbon and nitrogen circulation in the lakes, 214 (Moscow: Nauka, 1985)

11. I.N. Krylova, Nitrification and denitrification in various lakes. Dissertation Abstract of the Ph.D. in biological sciences, 24 (Moscow: MSU,1984)

12. A.V. Ryzhakov, Environmental chemistry, 21(2), 117 -124 (2012)

13. Order of the Ministry of Agriculture of the Russian Federation No.552 dated December 13, 2016 On approval of water quality standards for the fishery water bodies, including the standards for maximum permissible concentrations of harmful substances in the waters of fishery water bodies

14. A.A. Savkin, S.V. Fedorov, Hydrology: a training manual, 98 (Saint-Petersburg, 2010)

15. M.A. Zharsky, G. N. Rudkovskaya, Hydraulics, hydrology and meteorology: training aid, 292 (Gorki: The Buryat State Academy of Agriculture, 2013) 